\title{
Measuring Foreign Traveler's Satisfaction with Traveling Agencies in India
}

\author{
Rohit Singh Tomar ${ }^{1}$ Dr. Deepika S. Tomar ${ }^{2}$ \\ 1 (Management, Amity Business School/ Amity University Madhya Pradesh/India) \\ 2 (Management, Amity Business School/ Amity University Madhya Pradesh/India)
}

\begin{abstract}
Purpose: In India international tourist arrival is relatively less as compared to the other part of the world. The purpose of this research is to find out the dimensions of service quality which are responsible for customer satisfaction.

Design/Methodology/Approach: Data was collected through questionnaire, items suggested by Caro \& Garcia, 2008; it has been modified as per the needs of our research. Target population was foreign tourist coming to India via various travel agencies. We took sample of 164 tourists of various nations like Britain, Greece, Philippines, Finland, Malaysia and Poland touring India. A PASW 19.O is used for factor analysis and multiple regression.
\end{abstract}

Finding: In the current research we are able to find out two dimensions tangible (observable attribute) and intangible (felt attribute) important for the travel agents working in India. These two dimensions found to have a significant impact on customer satisfaction as well. Also satisfied customer intended to revisit the service provider and recommend others to use the same.

Research Limitation/ Implications: Small sample size of 164 foreign travelers representing few countries is not sufficient to represent large world population. Research requires more diversified sample. Use of non probability sampling is less suitable way to conduct research.

Practical implications: This study is useful for the travel agents working in India and hence enables them to provide better service quality which would further improve satisfaction level of their customers.

Originality/ Value: This paper is important as very few researches have been done to improve the service quality of travel agencies working in India.

Keywords: Customer satisfaction, Service quality, Travel agents, Travel Agency, Tourists.

\section{Introduction}

In India tourism is an important industry generating more than Rs.77591 crore (US \$ 15.56 billion) of valuable foreign exchange earnings and this is growing at the rate of $19.6 \%$. Travel and tourism industry generates both direct and indirect employment opportunities. Therefore importance of foreign tourist cannot be denied in India. Indian government is trying its best to attract foreign tourist through its incredible India program because of which growth rate of foreign travelers arrival in India is $8.9 \%$ in 2011 with a 6.29 million arrivals of foreign tourist in India. This growth is appreciable as compared to world's tourism industry with a growth rate of $4.6 \%$ in number of international tourist arrival. But, in India the share of international tourist arrival is $0.64 \%$ which is very less as compared to other countries like France, U.S.A, China and many others. Analyzing the causes of the low share of foreign tourist arrival in India is what is required. Through review of literature it has been found that customer satisfaction is an important parameter in travel and tourism industry. In India travel agents are striving to provide customer satisfaction through increasing service quality. Therefore the aim of the study is to measure the customer satisfaction of the foreign travelers in India with the travelling agencies. We would take the help of Nam and Lee , 2011, model developed for the restaurant, to work on the assumption that the customer satisfaction depend upon service quality and further a satisfied customer recommend and reuse / revisit the service provider which is travelling agency in our research. For this instrument developed by Caro and Garcia, 2008 is used to measure the service quality of the travel agency; it has been modified as per the need of our research. Caro and Garcia, 2008 conducted a study to find out the service quality dimensions for the travel agencies working in Spain. They find out three dimensions with seven sub dimensions which are (1) Personal Interaction - Conduct, Expertise and Problem Solving (2) Physical Environment - Equipment and Ambient Conditions (3) Outcome - Waiting Time and Valence. In our study firstly we would find out whether these dimensions are same in India or if any new dimension is coming. Secondly, influence of those dimensions of service quality which is independent variable would be tested on the customer satisfaction. Finally the Nam and Lee ,2011 model will be tested in India with travel agencies to find the influence of service quality as independent variable on the recommendation and revisit/reuse of the service providers. 


\section{Related Literature}

A research model is developed, influenced from the Nam and Lee model and on the basis of the previous study conducted by others (Figure 1). Customer satisfaction is an important theoretical as well as practical issue for most marketers and consumer researchers (Dabholkaret al., 1996). Consequently, customer satisfaction is increasingly becoming a corporate goal as more and more companies strive for quality in their products and services (Bitner and Hubbert, 1994). Also service quality that appears to be the causal antecedent of customer satisfaction (Anderson and Sullivan, 1993; Cronin and Taylor, 1992; Oliver, 1993; Taylor and Baker, 1994). This research will pave a path to establish an influence of service quality on customer satisfaction $\left(\mathrm{H}_{1}\right)$. Customer satisfaction is widely recognized as a key influence in the formation of customers' future purchase intentions (Taylor and Baker, 1994). Satisfied customers are also likely to tell others about their favourable experiences and thus engage in positive word of mouth advertising (Richens, 1983; File and Prince, 1992). Therefore customer satisfaction will influence the customer's intension to revisit/reuse $\left(\mathrm{H}_{2}\right)$ and intension to recommend $\left(\mathrm{H}_{3}\right)$ the travel agency. Earlier research conducted by Lam and Heung (1998), Dabholkar et al. (2000), Heung et al. (2002), Lee et al. (2004), and Ekinci et al. (2008) indicated positive association of service quality and customer satisfaction. While significant cause and effect relationship between customer satisfaction and future behavior have been found by Reichheld and Sasser,1990 ; Oliver, 1999, and Ekinci et al.,2008.

Research on customer satisfaction is often closely associated with the measurement of service quality (Anderson and Sullivan,1993 ; Cronin and Taylor,1992; Bittner and Hubbert 1994; Taylor and Baker,1994; Rust and Oliver, 1994; Levesque and Mcdougall,1996). Most studies have measured service quality by replicating and adapting the SERVQUAL model ( Fick and Ritchie,1991; Karatepe and Avei, 2001; Lewis,1987; Saleh and Rayan,1991). But there is a need to develop service quality measures that are industry and culture specific (Babacus and Boller,1992 ; Babacus and Mangold 1992; Carman, 1990; Mc Alexander, Dennis, and Koenig,1994; Keratepe et al.,2005; Mattila,1999 ). Hence in our research scale developed by Caro and Garcia,2008 is used to measure service quality dimensions in travelling agencies. Caro and Garcia, conducted research in Spain in 2008 and came with three major dimensions of service quality which have seven sub divisions. In our research we will conduct factor analysis taking these dimensions as base and come up with some factors suitable in India as far as service quality aspect of the travel agencies is concern. Johns et al. (2004) employed SERVQUAL to analyze service quality of travel agencies in Northern Cyprus. Factor analysis conducted by him showed an uni dimensionality which is consistent with other authors findings ( e.g., Babacus and Mangold,1992; Cronin and Taylor,1992; Karatepe and Avei, 2001).

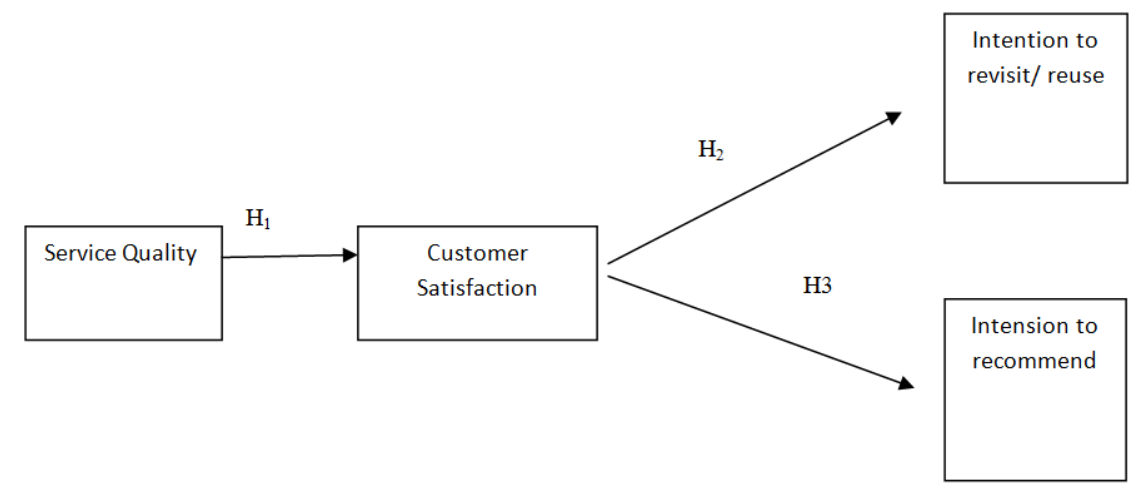

\subsection{Instrument}

III. Methodology

Measurement variables were taken from the previous researches. A seven point Likert scale is used. 14 items to measure service quality of the travel agents suggested by Caro and Garcia, 2008 were taken on modified scale. Further to measure impact of customer satisfaction and intension to recommend is added in the same questionnaire suggested by Cronin \& Taylor, 1992. Appendix -1 in the form of questionnaire has been attached to locate questions, variables and source.

\subsection{Data Collection \& Sample}

We are thankful to approved licensee of Ministry of Tourism and Culture for collecting valuable information required for conducting the study. Data was collected through questionnaire, items suggested by Caro \& Garcia, 2008; it has been modified as per the needs of our research. Tour escorts were trained to help tourist to fill required information in the questionnaire as these escorts were expert in the language spoken by 
the tourist. Target population was foreign tourist coming to India via various travel agencies. We took sample tourist of various nations like Britain, Greece, Philippines, Finland, Malaysia and Poland touring India by availing services from Le Passage to India Tours \& Travels P. limited and Kouni Tours and Travels P. limited. A total of 164 questionnaires were filled by the foreign tourist with the help of tour escorts.

55 males and 109 females were the respondents coming from countries like Britain (16), Greece (16), Finland (30), Malaysia (31), Philippines (41) and Poland (30). Most of tourist (60) are falling in the age group of 25 -50.From the data collected by us the average age of the tourist is found to be 50.5 years. Nearly $49.12 \%$ of the foreign tourists visiting India belonged to the age-group thirty six to sixty five as per the international passenger survey 2003 conducted by Ministry of Tourism, Government of India. Average number of days spend by them in India are 10 days, ranging from 04 days to 22 days. They visited Agra, Khajuraho, and some parts of Rajasthan in India.

Validity and reliability of the scale

\section{Results}

14 items of scale suggested by Caro and Garcia, 2008 were subjected to factor analysis using SPSS 19.0. Before conducting factor analysis the suitability of the data is tested by Kaiser-Meyer-Oklin statistic to check sampling adequacy which is measured to be 0.920 , exceeding the recommended value of 0.6 (Kaiser 1974) and in Bartletts' test of sphericity the chi-square value is 3374 with 91 degree of freedom which is significant at 0.05 level. Therefore data is suitable for the factor analysis.

The final result of Principal component analysis with a varimax rotation matrix rotation suggested a two factor solution. The result of factor analysis shows two factors instead of three factors suggested in earlier research. These factors were selected because their eigenvalue was greater than one with total variance of $85 \%$.Indiidual variance is represented in Table 1. Factor loading of each component is shown in Table 2.

Results of factor analysis for the modified scale

Raw

\begin{tabular}{llll} 
Factor & Eigenvalue & $\%$ of variance & Cumulative \\
\hline 1 & 11.680 & 40.994 & 40.994 \\
2 & 12.589 & 44.187 & 85.187
\end{tabular}

Rescaled

$\begin{array}{lrrr}1 & 6.738 & 48.130 & 48.130 \\ 2 & 5.059 & 36.136 & 84.266\end{array}$

Table: 1 rotated sums of squared loadings

\begin{tabular}{|c|c|c|}
\hline \multirow[t]{2}{*}{ Scale } & \multicolumn{2}{|c|}{ Factor Loading } \\
\hline & Factor1 & Factor2 \\
\hline In my opinion company's employees seek the best for the customer & 0.869 & \\
\hline I feel that the attitude of the company's employees demonstrate the willingness to help me & 0.823 & \\
\hline In my opinion the employees are competent & 0.750 & \\
\hline I feel that when a customer has a problem, this company shows a sincere interest in solving it & 0.858 & \\
\hline In my opinion the employees are able to handle customer complaints efficiently & 0.772 & \\
\hline I feel that this company provides services to the consumers punctually & 0.699 & \\
\hline In my opinion this company show its interest in accelerating the services & 0.831 & \\
\hline When I leave this company I always feel that I got what I wanted & 0.825 & \\
\hline You would evaluate the outcome of this service favorably & 0.762 & \\
\hline I feel the employees have knowledge enough about different services to respond to customer's services & & 0.828 \\
\hline I feel that the equipment used by the company is in good condition & & 0.891 \\
\hline In my opinion the employees have a neat and professional appearance & & 0.949 \\
\hline I feel that the office ambiance of the company is appropriate & & 0.702 \\
\hline I feel that the office of the company is safe and comfortable & & 0.695 \\
\hline
\end{tabular}

Table: 2 rotated component matrix

Extraction Method: Principal Component Analysis, Rotation Method: Varimax with Kaiser Normalization. Interpretations of extracted factors are slightly different from the earlier research. In the earlier research three dimensions having seven sub dimensions came out but in our research conducted in India two factors are extracted. In Table 3 classifications of earlier dimensions is shown with current factors. 


\begin{tabular}{|l|l|}
\hline Current Factors obtained & Possessing earlier research dimensions \\
\hline Factor 1 & $\begin{array}{l}\text { Personal Interaction ( Conduct + Problem Solving) + Employee Competency (Q.4 Appendix I , } \\
\text { Under sub dimension Expertise ) + Outcome ( Waiting Time + Valence ) }\end{array}$ \\
\hline Factor 2 & $\begin{array}{l}\text { Physical Environment ( Equipment + Ambiance ) + Employees Knowledge of Services (Q.3 } \\
\text { Appendix I, Under sub dimension Expertise) }\end{array}$ \\
\hline
\end{tabular}

Table: 3

\begin{tabular}{|l|l|l|l|}
\hline Variables & Customer Satisfaction & $\mathrm{p}$ - value \\
\hline & Beta & t-value & 0.00 \\
\hline Felt attribute (intangible) & 0.649 & 8.501 & 0.014 \\
\hline Observable attribute(tangible) & 0.191 & 2.497 & \\
\hline $\mathrm{R}^{2}$ & 0.655 & & \\
\hline $\mathrm{F}$ & 152.978 & & \\
\hline $\mathrm{p}$ & 0.00 & & \\
\hline
\end{tabular}

From Table 3 we can infer factor 1 as Felt Attribute which are intangible in nature while factor 2 is Observable attribute which are tangible in nature including employee knowledge of the service which is the articulate knowledge of the travel agents about their services which could be tangibly felt by the customer. Therefore earlier 3 factors could be squeezed into two factors while measuring travel agency's service quality in India.

Now, model one is baptized with two dimensions of service quality felt attribute of service quality and observable attribute of service quality.

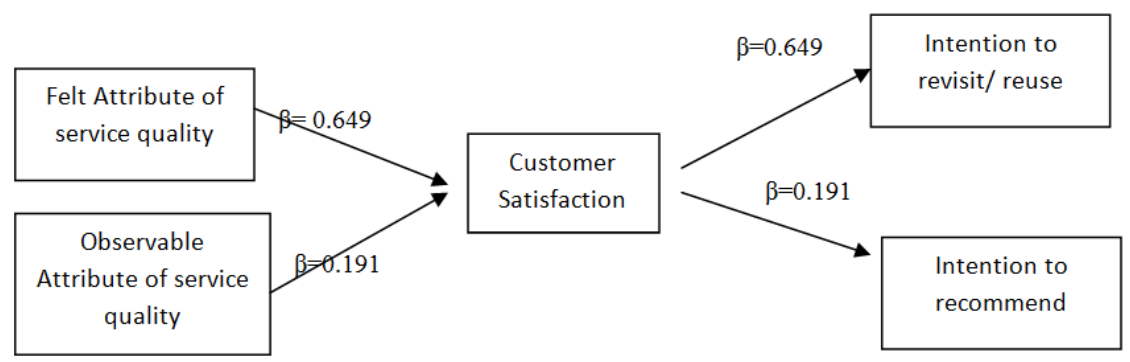

Fig.2: analyzed research model

The factor analysis confirms the two dimensions of service quality namely felt attribute and observable attribute. One of the aims of the study is to examine antecedents affecting foreign travelers' satisfaction with the travel agencies working in India. Therefore following hypothesis is generated:

H1a. The felt attribute of service quality dimension has a positive impact on customer satisfaction.

H1b. The observable attribute of service quality dimension has a positive impact on customer satisfaction

For testing the above hypothesis, multiple regression analysis is conducted to test the antecedents of customer satisfaction. Two dimensions of service quality felt attribute (intangible attribute) and observable attribute (tangible attribute) obtained from earlier analysis are considered as independent variable and customer satisfaction is considered as dependent variables. Results of the analysis are given in below table.

Table: 4 estimating customer satisfaction: multiple regression analysis

Table 4 shows the regression model is statistically significant in estimating customer satisfaction $\left(R^{2}=0.655\right.$; $\mathrm{F}=152.978 ; \mathrm{P}<0.00) . \mathrm{R}^{2}=0.655$ explained $65.5 \%$ of variance in customer satisfaction. The $\beta$ coefficient of felt attribute (intangible) is 0.649 which is much higher than the 0.191 value of $\beta$ coefficient of observable attribute (tangible). These analyses have revealed that both factors have significant impact on the customer satisfaction, hence hypothesis H1a and H1b are supported.

Another aim of this study is to find out whether the customer satisfaction affects future decisions of the customer, therefore test two hypothesis are generated:

H2: Satisfaction has a positive impact on the customer's intension to revisit / reuse the services.

H3: Satisfaction has a positive impact on the customer's intension to recommend.

To test these hypotheses a simple regression analysis is performed, customer satisfaction is considered as independent variable and customer intension to revisit and intension to recommend is considered as dependent variable. Table 5 shows the simple regression analysis between the customer satisfaction and intension to revisit/reuse and customer satisfaction and intension to recommend. 
$\mathrm{R}^{2}$ value indicates that customer satisfaction explains $88.8 \%$ of variance in intension to revisit. This is statistically significant at the 0.00 level. The results indicate that customer satisfaction has significant impact on customer intension to revisit/reuse. Therefore $\mathrm{H} 2$ is supported. Similarly the $\mathrm{R}^{2}$ value of the customer satisfaction explains $86.3 \%$ of variance in intension to recommend. This is also statistically significant at 0.00 levels. The results indicate that customer satisfaction has significant impact on the customer intension to recommend. Therefore H3 is also supported. These findings are proved by the earlier researchers mentioned in literature review. Analyzed model is given in fig. 2.

Table 5: estimating intension to revisit/reuse and intension to recommend: simple regression analyses.

\begin{tabular}{|c|c|c|c|c|c|c|}
\hline Variable & \multicolumn{3}{|c|}{ Intension to revisit/reuse } & \multicolumn{3}{|c|}{ Intension to recommend } \\
\hline & Beta & t-value & $\mathrm{p}$-value & Beta & $\mathrm{t}$-value & p-value \\
\hline $\begin{array}{l}\text { Customer } \\
\text { Satisfaction }\end{array}$ & 0.942 & 35.755 & 0.00 & 0.929 & 31.952 & 0.00 \\
\hline $\mathrm{R}^{2}$ & \multirow{3}{*}{\multicolumn{2}{|c|}{$\begin{array}{l}0.888 \\
1278.419 \\
0.00\end{array}$}} & & \multirow{3}{*}{$\begin{array}{l}0.863 \\
1020.915 \\
0.00\end{array}$} & & \\
\hline $\mathrm{F}$ & & & & & & \\
\hline $\mathrm{P}$ & & & & & & \\
\hline
\end{tabular}

\section{Conclusion}

By observing demographic data of the travelers or the customers of the travel agency it has been found that most of the foreign travelers coming to India belong to elderly group with average age of 50.5 years. Travel agencies working in India must concentrate upon the needs of the elderly tourist they should design their travel package to meet the requirements of the travelers belonging to this age group. Therefore comfortable and less hectic schedule could be designed for the foreign travelers visiting India. Although this has not been tested imperially in this research as it was not the aim of the current research, further research is what is required in this scenario.

From our study yet again it is proved that service quality is an important antecedent of the customer satisfaction. Two compressed dimension important for the service quality provided by the travel agencies in India have been come out which are felt attribute and observable attribute which are nothing but the intangible and tangible aspects of the service quality respectively. Service quality in travel agency depends more upon the felt attribute (intangible) than the observable attribute (tangible). Therefore travel agencies must focus more on personal interaction, employee competency and outcome (waiting time+ valance), which are intangible attributes. Working upon these dimensions eventually gives satisfaction to the customers (travelers). Employee's neat and professional appearance along with equipments used by the company is equally important as they have the maximum factor loading. Safety and comfort of the foreign travelers required some attention this is also supporting the fact that these travelers are elderly as elderly people need both. These are the part of the observable attribute or tangible attribute. Customer satisfaction also depends upon these two dimensions. A satisfied customer is willing to revisit / reuse the services he would be enthusiastic enough to recommend others to use the services.

This research is however useful in understanding service quality and customer satisfaction of the foreign travelers visiting India by availing services of travel agencies, but it also has certain limitations. Small sample size of 164 foreign travelers representing few countries like England, Poland, Greece, Finland, Malaysia and Philippines is not sufficient to represent large world population. Research requires more diversified sample. Use of non probability sampling is less suitable way to conduct research and invites scope of future research using comprehensive sampling plan.

\section{References}

[1]. Anderson, Eugene and Mary W. Sullivan (1993), "The Antecedents and Consequences of Customer Satisfaction for Firms," Marketing Science, 12 (No. 2, Spring), 125-43.

[2]. Babakus, E., \& Boller, G.W., 1992. An empirical assessment of the SERVQUAL scale. Journal of Business Research, 24, $235-268$.

[3]. Babakus, E., \& Mangold, D.W.G., 1992. Adapting the SERVQUAL scale to hospital services: and empirical investigating. Health services research, 26(6), 767-786.

[4]. Bitner, M.J., \& Hubbert, A.R., 1994. Encounter satisfaction versus overall satisfaction versus quality. In R. Rust \& R. Oliver ( Eds. ), service quality : New directions in theory and practice, 72-94. London: Sage Publications, Inc.

[5]. Carman, J., 1990. Consumer perception of service quality : An assessment of the SERVQUAL dimensions. Journal of Retailing, 66, $33-55$.

[6]. Caro, L.M., Garcia, J.A.M., 2088. Developing a multidimensional and hierarchical service quality model for the travel agency industry. Tourism Management 29, 706-720.

[7]. Cronin, J. Joseph, Jr. and Steven A. Taylor (1992), "Measuring Service Quality: A Reexamination and Extension," Journal of Marketing, 56 (July), 55-66.

[8]. Dabholkar, P.A., Thorpe, D.I., \& Rentz, J.O., 1996. A measure of service quality for retail stores : scale development and validation. Journal of academy of marketing science, 24 (1), 3-16. 
[9]. Dabholkar, P.A., Shepherd, C.D., D.I., 2000. A comprehensive framework for service quality: an investigation of critical conceptual and measurement issues through a longitudinal study. Journal of Retailing 76(2), 139-173.

[10]. Ekinci, Y., Dawes, P., Massey, g., 2008. A model of consumer satisfaction for services. European Journal of Marketing 42 (1), $35-68$.

[11]. Fick, R.P., \& Ritchie, R.B.,1991. Measuring service quality in the travel and tourism industry. Journal of Travel Research, 30 (2), 29.

[12]. File,K.M., \& Prince, R.A., 1992. Positive word-of-mouth: Customer satisfaction and buyer behavior. International Journal of Bank Marketing 10(1), 25-29.

[13]. Heung, C.S., Wong, M.Y., Qu, H.,2002. A study of tourists' satisfaction and post experience behavioral intensions in relation to airport restaurant services in Hong Kong SAR. Journal of Travel and Tourism Marketing 12 (2/3), 111-135.

[14]. Johns, N., Avei, T., \& Karatepe, O., 2004. Measuring service quality of travel agents: Evidence from Northern Cyprus. The service industry Journal, 24(3), 82-100.

[15]. Karatepe, O.M., \& Avei, T., 2001. Trait validity assessment of a service quality measure: Evidence from loading service in northern Cyprus. Eastern Mediterranean University, school of Tourism and Hospitality management.

[16]. Karatepe, O.M., Yavas , U., \& Babakus, E., 2005. Measuring service quality of banks: Scale development and validation. Journal of Retailing and Consumer Services, 12, 373-383.

[17]. Lam, T., Heung, V.C.S.,1998. University food service in Hong Kong : a study of consumers' expectations and satisfaction levels. Journal of college and University Food service 3 (4), 3-12.

[18]. Lee, J., Graefe, A.R., Burns, R.C., 2004. Service quality, satisfaction, and behavioral intension among forest visitors. Journal of Travel and Tourism Marketing 17(1), 73-82.

[19]. Levesque, T., \& Mc Dougall, G.H.G., 1996. Determinants of customer satisfaction in Retail Banking. International Journal of Bank Marketing, 7, 12-20.

[20]. Lewis, R.C.,1987. The measurement of gaps in the quality of the hotels services. International Journal of Hospitality Management, 6, 38-88.

[21]. Mattila, A.S.,1999. The role of culture in the service evaluation process. Journal of service research, 1(3), $250-261$.

[22]. Marsha L. Richins (1983), "An Analysis of Consumer Interaction Styles in the Marketplace," Journal of Consumer Research, 10 (June), 73-82. Featured the Word of Mouth Marketing Association Newsletter and blog, November 2006.

[23]. Mc Alexander, J.H.K., Dennis, O., \& Koenig, H.F., 1994. Service quality measurement. Marketing health services, 14(3), 33 -44.

[24]. Nam, J.H., Lee, T.J., 2011. Foreign travelers' satisfaction with traditional Korean restaurants. International Journal of Hospitality Management 30, 982-989.

[25]. Oliver, R.L., 1993. Cognitive, affective, and attribute bases of the satisfaction response. Journal of consumer research, 20, 418-430.

[26]. Oliver, R.L., 1999. Whence consumer loyalty ? Journal of Marketing 63 ( Special issue ), 33-44.

[27]. Riechheld, F.F., Sasser, E.W., 1990. Zero defections: quality comes to service. Harvard Business Review 68 (5), $105-116$.

[28]. Saleh, F., \& Rayan, C., 1991. Analysing service quality in the hospitality industry using the SERVQUAL model.

[29]. Spring, R.L., Mackoy, R.D., 1996. An empirical examination of a model of perceived service quality and satisfaction. Journal of Retailing 72 (2), 201-214.

[31]. Taylor and Baker, Journal of retailing, June 1994, volume 70, pg. 163-178.

[32]. Tourism Statistics at a glance,2011 incredible India, market research division, ministry of tourism, government of India , New Delhi[1].

\section{Appendix I}

\section{Questionnaire}

This questionnaire has been designed to measure the customer satisfaction of the foreign travelers' with the traveling agencies in India. Information generated through this questionnaire would be used only for the research work.

Part - I

\section{Name of the respondent:}

\section{Nationality:}

\section{Age in Years:}
4. Gender: (i) Male
5. Education:
(ii) Female

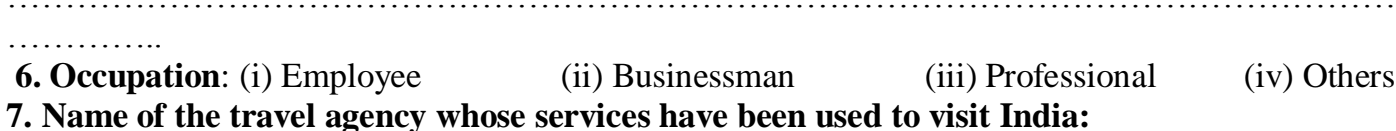

\section{Name of the travel agency whose services have been used to visit India:}

\section{Duration of the visit:}

\section{Month of the visit:}


Part - II

Kindly tick your response ranging from strongly disagree (SD) to strongly agree (SA) on the 7-point dichotomous scale.

\begin{tabular}{|c|c|c|c|c|c|c|c|c|}
\hline S.No & Items & S.D & \multicolumn{5}{|c|}{ 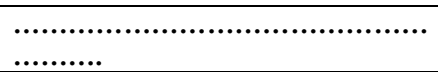 } & S.A \\
\hline \multicolumn{9}{|c|}{ Service quality of the travel agency (Caro and Garcia, 2008) } \\
\hline 1. & $\begin{array}{l}\text { In my opinion company's employees seek the best for the } \\
\text { customer }\end{array}$ & 1 & 2 & 3 & 4 & 5 & 6 & 7 \\
\hline 2. & $\begin{array}{l}\text { I feel that the attitude of the company's employees } \\
\text { demonstrate the willingness to help me }\end{array}$ & 1 & 2 & 3 & 4 & 5 & 6 & 7 \\
\hline 3. & $\begin{array}{l}\text { I feel the employees have knowledge enough about different } \\
\text { services to respond to customer's services }\end{array}$ & 1 & 2 & 3 & 4 & 5 & 6 & 7 \\
\hline 4. & In my opinion the employees are competent & 1 & 2 & 3 & 4 & 5 & 6 & 7 \\
\hline 5. & $\begin{array}{l}\text { I feel that when a customer has a problem, this company } \\
\text { shows a sincere interest in solving it }\end{array}$ & 1 & 2 & 3 & 4 & 5 & 6 & 7 \\
\hline 6. & $\begin{array}{l}\text { In my opinion the employees are able to handle customer } \\
\text { complaints efficiently }\end{array}$ & 1 & 2 & 3 & 4 & 5 & 6 & 7 \\
\hline 7. & $\begin{array}{l}\text { I feel that the equipment used by the company is in good } \\
\text { condition }\end{array}$ & 1 & 2 & 3 & 4 & 5 & 6 & 7 \\
\hline 8. & $\begin{array}{l}\text { In my opinion the employees have a neat and professional } \\
\text { appearance }\end{array}$ & 1 & 2 & 3 & 4 & 5 & 6 & 7 \\
\hline 9. & I feel that the office ambiance of the company is appropriate & 1 & 2 & 3 & 4 & 5 & 6 & 7 \\
\hline 10. & I feel that the office of the company is safe and comfortable & 1 & 2 & 3 & 4 & 5 & 6 & 7 \\
\hline 11. & $\begin{array}{l}\text { I feel that this company provides services to the consumers } \\
\text { punctually }\end{array}$ & 1 & 2 & 3 & 4 & 5 & 6 & 7 \\
\hline 12. & $\begin{array}{l}\text { In my opinion this company show its interest in accelerating } \\
\text { the services }\end{array}$ & 1 & 2 & 3 & 4 & 5 & 6 & 7 \\
\hline 13. & $\begin{array}{l}\text { When I leave this company I always feel that I got what I } \\
\text { wanted }\end{array}$ & 1 & 2 & 3 & 4 & 5 & 6 & 7 \\
\hline 14. & You would evaluate the outcome of this service favorably & 1 & 2 & 3 & 4 & 5 & 6 & 7 \\
\hline
\end{tabular}

Kindly tick your response ranging from Extremely Dissatisfied (EDS) to Extremely Satisfied (ES) on the 7point dichotomous scale.

\begin{tabular}{|c|c|c|c|c|c|c|c|c|}
\hline S. No. & Item & EDS & & & & & & ES \\
\hline \multicolumn{9}{|c|}{ Customer Satisfaction (Spreng and Mackoy , 1996) } \\
\hline 15. & Are you satisfied with the services of the company & 1 & 2 & 3 & 4 & 5 & 6 & 7 \\
\hline
\end{tabular}

Kindly tick your response ranging from Extremely Unlikely (EUL) to Extremely Likely (EL) on the 7-point dichotomous scale.

\begin{tabular}{|c|c|c|c|c|c|c|c|c|}
\hline S.No. & Item & EUL & \multicolumn{5}{|c|}{ 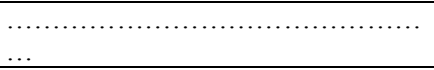 } & EL \\
\hline \multicolumn{9}{|c|}{ Intension to revisit ( Cronin and Taylor, 1992 ) } \\
\hline 16. & $\begin{array}{l}\text { Do you intent to reuse/revisit the services provided by your } \\
\text { travel agent }\end{array}$ & 1 & 2 & 3 & 4 & 5 & 6 & 7 \\
\hline \multicolumn{9}{|c|}{ Intension to recommend ( Cronin and Taylor,1992) } \\
\hline 17. & $\begin{array}{l}\text { Do you intend to recommend this service to your friends / } \\
\text { relatives }\end{array}$ & 1 & 2 & 3 & 4 & 5 & 6 & 7 \\
\hline
\end{tabular}

